\title{
Una experiencia de educación plástico visual en la sala de un año
}

\author{
Stella Maris Martín
}

Palabras clave. políticas educativas · falsos problemas . enseñanza $\cdot$ aprendizaje y evaluación .

entornos culturales de aprendizajes

Resumen. El siguiente artículo presenta una experiencia áulica cuyo eje central es el lenguaje plástico visual. A través del abordaje del mismo, y de su inclusión en la sala de un año, se intenta resignificar algunas concepciones y prácticas tradicionales fuertemente arraigadas en el Nivel Inicial.

Con ello se pretende superar la inadecuada implementación de las Ilamadas técnicas grafoplásticas, haciendo especial hincapié en las posibilidades de los niños sin subestimarlos tomando en cuenta sus necesidades, intereses y el contexto en el que se encuentran insertos.

De esta forma, a través de la observación de reproducciones de las obras del artista Juan Arancio y de la exploración gráfica con diferentes herramientas, se propone un trabajo integrado, secuenciado, con una finalidad propia que incluye los dominios descritos por Elliot Eisner. Se intenta trabajar con este tipo de lenguaje que, como cualquier otro, necesita ser enseñado incluso desde edades muy tempranas, y resulta muy beneficioso en muchos aspectos para los niños.
Keywords. Plastic visual language - new meaning · one-year-olds' classroom · artistic learning domains

Abstract. The following article introduces a classroom experience centered in plastic visual language. It is through this approach, and its application in the one-year-olds' classroom, that it is attempted to give new meaningto some traditional concepts and practices which are strongly rooted in kindergarten.

Though all this it is aimed to overcome the inadequate implementation of the so-called graphoplastic techniques emphasizing the toddlers' possibilities taking into account their needs, interests, and the environment they are used to interact in.

This, through the observation of artist Juan Arancios' works and the graphic scanning using several tools, this paper intends to achieve an integrated, sequenced note aiming at the domains described by Elliot Eisner. This is the way in which this language that, just like any other language, needs to be taught even from early ages, to be highly beneficial in various aspects in toddlers' lives.

(1) Jardín «La Ronda», Universidad Nacional del Litoral. stella.m.martin@gmail.com

itinerarios educativos 8 - 8 - 2015 